\title{
Modern Constitutional Legitimacy and Political Theology: Schmitt, Peterson and Blumenberg
}

\author{
Nathan Gibbs ${ }^{1}$ iD \\ Published online: 10 August 2018 \\ (C) The Author(s) 2018
}

\begin{abstract}
In this article, an important set of general themes will be examined in relation to the ongoing problematization of the legitimacy of modern constitutionalism within a body of work that largely draws on Carl Schmitt's political theology. In particular, however, the themes discussed in this article will focus on the later, post-war stages of his work contained in the brief, but dense volume entitled, Political Theology II. This work involves a sustained confrontation with the theologian Erik Peterson and the historian of ideas Hans Blumenberg, a confrontation which helps to shed light on the broader significance of Schmitt's work.
\end{abstract}

Keywords Blumenberg · Constitutionalism · Erik Peterson · Modernity · Political theology $\cdot$ Schmitt

\section{Introduction: The Theme of Political Theology in the Debate Over the Concept of the Political}

In this article, an important set of general themes will be examined in relation to the on-going problematization of the legitimacy of modern constitutionalism within a body of work that largely draws on Carl Schmitt's political theology. In particular, however, the themes discussed in this article will focus on the later, post-war stages of his work contained in the brief, but dense volume entitled, Political Theology II (Schmitt 2008). This work involves a sustained confrontation with the theologian Erik Peterson and the historian of ideas Hans Blumenberg, a confrontation which helps to shed light on the broader significance of Schmitt's work (Blumenberg 1983). What exactly is at stake in these debates?

The on-going scholarly engagement with Carl Schmitt's work has highlighted some key themes regarding the nature of judicial discretion in the interpretation of

Nathan Gibbs

njg@aber.ac.uk

1 Department of Law and Criminology, Aberystwyth University, Aberystwyth SY23 3FL,

Wales, UK 
law, the relationship between liberal constitutionalism and constituent power, the state of exception and extraordinary constitutional powers, the antagonistic nature of political activity as well as the broader theme of political theology. It has also helped to consolidate an important distinction between politics and the political which has enabled a more nuanced attempt to distinguish more fundamental and determinative 'moments' of political experience from more quotidian and conditioned elements that often operate within a limited form of instrumental rationality and bureaucratic power. ${ }^{1}$ A focus on Schmitt's later work in the light of the linked set of dialogues with Blumenberg and Peterson enable this range of themes to be drawn together with reference to three critical and interconnected issues: constituent power, antagonism and political theology. These issues are further best interpreted as connected to an underlying problem: the nature of constitutional legitimacy in the modern age.

The course of the following discussion will seek to set out a particular understanding of the problem of legitimacy in contemporary constitutionalism. These ideas will then be used to develop a challenge to attempts to resolve the legitimacy problem through deploying ideas of political antagonism (one of the most salient approaches suggested by leading interpreters of Carl Schmitt's work). At the same time it seeks to do justice to the specific historical setting of the problem of legitimacy in the modern epoch, a problem to which the notion of political antagonism was also intended to provide a response. This is done through a careful exploration of Schmitt's nuanced understanding of the topic of political theology and his debates with Erik Peterson and Hans Blumenberg. Further examination of these points, especially in the light of the work of Erik Peterson and Hans Blumenberg help to reveal how an 'associationalist' rather than an 'antagonistic' reading of the dimension of the political can nevertheless be developed which would contribute to a renewed understanding of contemporary constitutionalism capable of escaping the limits of market rationality and bureaucratic logic. ${ }^{2}$ Reflection on this difference between the antagonistic and associationalist understanding of the fundamental level of political agency, the level of the political, is arguably the central question currently facing constitutional theory and action with regard to problems of legitimacy. In brief, the antagonistic reading of the political has its most powerful advocate in Carl Schmitt and emphasizes existential enmity as the pivotal concept in political

\footnotetext{
1 This is often put in philosophical terms that stem from Heideggerian phenomenology as a distinction between the ontological (the political) and the ontic (politics). Its importance in understanding a variety of contemporary 'post-structuralist' approaches to political theory is set out in Marchart (2007). For such post-structuralist thinkers the emphasis is often placed on a foundational 'moment' precisely to indicate that the foundation cannot itself be objectively determined and adequately conceptualized but is rather better interpreted in terms of temporal categories like that of an event. Although, it is risky to read some of the latter developments of this line of thinking back into Schmitt's work, Schmitt's notion of political theology has significant points of commonality. There is, first, the sense that Schmitt grounds politics in a certain sort of founding 'moment' that has a fluid existential character: a sovereign decision. Second, there is Schmitt's insistence of the 'autonomy' of this 'moment' precisely as foundational: the sovereign decision as its own criterion, the friend-enemy distinction which is not reducible to a more fundamental criterion drawn from economics, ethics and so on.

${ }^{2}$ For the distinction between 'associationalist' and 'antagonistic' interpretations of the political see Marchart (2007) and in particular chapter 2.
} 
life whilst the associationalist reading gives priority to the formation of political friendship through dialogue. Both perspectives have been pursued from both left and right, and from within different traditions. From a Hegelian-Marxist perspective, an antagonistic perspective has been developed by Laclau and Mouffe whilst an associationalist perspective on the political was developed by Jürgen Habermas with his notion of communicative action. Carl Schmitt's antagonistic political theory likewise seems connected to an existential or phenomenological starting point similar, in this methodological sense, to Arendt's opposed associationalist emphasis on the shared space of public speech or to John Milbank's and Radical Orthodoxy's emphasis on a Christian ontology and meta-narrative of peace in opposition to a pagan or 'secularist' ontology of violence (Milbank 2006; Milbank and Pabst 2016).

As stated, the exploration of this tension between antagonistic and associationalist readings of the political will be pursued in this article through an examination of the problem of political theology as it develops in Schmitt's engagement with Blumenberg and Peterson. The choice of this approach is not simply guided by the exegetical interest as to why Schmitt chose the confrontation with Blumenberg and Peterson as the terrain of his re-engagement with the theme of political theology in the post-war context. It is also guided by the sense that significant progress can be made in illuminating the confrontation between antagonistic and associationalist conceptions of the political by searching for an underlying theme-the theme of political theology - that has the historical and philosophical breadth to set out the prior 'political' stakes of this debate; in other words, the transcendent features of human agency that surpass particular institutional and social forms of life. Without this broader sphere of reflection on fundamental questions of ontology, historicity and anthropology, there is the danger of collapsing both associationalist and antagonistic perspectives into a limited tactical and institutional frame that dilutes their critical power. For example, in the work of Jürgen Habermas, there seems to be a tendency in his later work to tie the critical potentiality of the early notion of communicative action to an inchoate ideal-type liberal democracy and in the work of Lefort and Mouffe, as will be discussed, there seems to be too quick an assumption that the raw fact of political antagonism can be translated and domesticated into a more benign agonic form compatible with present forms of liberal constitutionalism and practice.

The idea of taking up the theme of political theology as a fruitful line of inquiry into clarifying the distinction between politics and the political, an inquiry that takes seriously the problem of transcendence proposed by the latter, has already been prefigured in the work of Claude Lefort. For Lefort, an ineliminable historicity and contingency that characterizes and contextualizes human action forms the background for thinking about the necessary role of a religious imaginary or of a political theology in symbolizing this contingency in the process of instituting social and political relations. The complexity of the historical background of human action provides a genuinely transcendent framework which resists mastery in terms of any type of human action whether instrumental or communicative. For Lefort, modern constitutionalism at its healthiest is characterized by a self-consciousness of the act of instituting the social order, an awareness of the underlying historical contingencies out of which certain forms of political and social order emerge. Instead of a fixed 
symbolic representation of this transcendent structure of human agency, this structure is acknowledged by the symbolic openness of modern political forms. In that sense, the structural position of political theology is retained in an open symbolic form as a crucial element of a healthy form of modern constitutionalism. The dangers of modern totalitarianism arise where this implicit awareness of a fundamental historical contingency is covered over in favour of the self-conscious projection and implementation of an imaginary societal unity. This totalitarian potential is held in check by a commitment to democratic institutions and human rights instruments that provide flexible modalities for collective or individual contestation of rigid schemes of social unity. ${ }^{3}$

Although Lefort's work usefully synthesizes a number of diverse intellectual currents into his conception of political theology and the dilemmas of modern constitutionalism to produce a convincing picture of the fundamental characteristics of liberal democracy, it is arguable that in so doing, he has moved too quickly to close down the range of problems disclosed by the concept of the political and by the theme of political theology. For Lefort, liberal-democracy emerges as the only lucid and non-totalitarian political response to the ultimate fact of a basic form of historical contingency. Thus, for Lefort, what is an essentially cognitive move is ultimately at stake in the problem of political theology: the function of a discourse on political theology is to reveal the essential character of modern constitutional thinking to itself. This does not seem to do justice to the specific existential human drama of antagonism and association which Schmitt's original problematic had disclosed in relation to this theme. In that sense, although Lefort deploys the concept of political theology, he arguably does not succeed in coming to terms with its fundamental existential stakes. In order to address both the problem of political theology as well as that of antagonism and associationalism, we arguably need to return to Schmitt's original problematic before going on to assess the work of two of his critics who, by Schmitt's admission, challenge his basic position in a fundamental way: Blumenberg and Erik Peterson.

Accordingly, the first section explains the importance of the themes of political theology and antagonism in articulating the contemporary constitutional significance of Carl Schmitt's work. In brief, Schmitt's work highlights the sense in which an antagonistic understanding of the political is inherently connected with an authoritarian or arguably totalitarian form of politics that unites a society around a comprehensive collective identity and world-view, a connection expressed in his understanding of political theology. His claim is that these connections are inherent to the moment of the political: an unavoidable dimension of human existence. The second and third sections together move the problem of political theology and its relationship to modern constitutionalism to a more historical setting using the work of Hans Blumenberg and Karl Löwith and their debate concerning Löwith's secularization thesis. Accordingly, the second section explains Karl Löwith's thesis that there is a distinctive 'political theology' of modern constitutionalism, a theology

\footnotetext{
${ }^{3}$ For an overall discussion of Lefort see Flynn (2005) and, on the theme of political theology, see Lefort's essay 'The permanence of the theologico-political?' in Lefort (1988).
} 
undermined by its reliance on an illegitimate secularization of the Christian eschatological understanding of history. In this respect, Löwith affirms Schmitt's thesis but with a basic scepticism regarding the legitimacy of political theology. The third section then proceeds to examine Blumenberg's alternative conception of modern constitutional legitimacy, and the historical awareness that accompanies it. Blumenberg's work is designed to counter the 'secularization' thesis, set out by Schmitt and Löwith, regarding the continuing role of political theology in modernity and he puts forward instead, what he terms, the ideal of self-assertion. The ideal of self-assertion is designed to provide an alternative reading of the historical material reviewed by Löwith with a view to establishing a move beyond the horizon of political theology. The fourth section reviews the subsequent debate between Schmitt and Blumenberg over the latter's concept of self-assertion, a debate which reveals critical limitations in the capacity of Blumenberg's concept to explore the interpersonal and ethical dimensions and dynamics of contemporary constitutionalism. The fifth section sets out an alternative way of conceptualizing the nature of constitutional authority that draws on the lessons of the Schmitt-Blumenberg debate. Through an examination of Erik Peterson's work, it locates the potential for an associationalist alternative to Schmitt's antagonistic reading of the interpersonal dynamics of the political. It explores how an authentic theology of the status of political theology opens up a specific historical constellation in which interpersonal association can emerge as a fundamental option for social and political agency.

\section{Section 1: Carl Schmitt's Political Theology and the Sphere of the Political}

Schmitt's engagement with modern constitutionalism can generally be interpreted in a number of distinctive ways. The most influential of these readings tend however to attempt to disclose the basic intent and premises of Schmitt's analyses in his key inter-war works. One sort of view, perhaps best represented by William Scheuerman, is that Carl Schmitt's critique of modern liberal constitutionalism is best interpreted in the context of the specific set of debates that were taking place in inter-war Germany about the stability of the Weimar settlement (Scheuerman 1999). Its ongoing hermeneutic value, at least as far as Scheuerman is concerned, is that it warns us of the dangers of exaggerating diagnoses of the indeterminacy and incoherence of the law in ways that would undermine the ideal of the rule of law. In this article, I would like to pursue a second possible hermeneutic strategy which seeks to take seriously the underlying thematic of political theology in Carl Schmitt's work in connection with the notion of the political. It is this dimension of Schmitt's work that arguably locates its fundamental importance in relation to the historical framing of the modern problem of constitutional legitimacy as well as conflicting visions of associational and antagonistic readings of the political.

The key themes of political theology and of the founding 'moment' of the political in Schmitt can usefully be introduced in relation to the apparently methodological discussions about the nature of a 'sociology' of juridical concepts that takes place in Political Theology. In this discussion, Schmitt is careful to distinguish what 
he regards as the proper function of the sociology of juridical concepts. According to him, it cannot be a case of tracing 'a conceptual result back to a sociological carrier' (Schmitt 2008, p. 44). This is, of course, the most general understanding of what the sociology of law amounts to. By ruling this solution out, Schmitt indicates that he is searching for a more autonomous 'political' grounding for fundamental legal concepts that resists sociological reduction. Accordingly, for Schmitt, the sociology of legal concepts instead 'aims to discover the basic, radically systematic structure [of law] and to compare this conceptual structure with the conceptually represented social structure of a certain epoch. ${ }^{4}$ As an example, he states that

it is a sociology of the concept of sovereignty when the historical-political status of the monarchy of that epoch is shown to correspond to the general state of consciousness that was characteristic of western Europeans at that time, and when the juristic construction of the historical-political reality can find a concept whose structure is in accord with the structure of metaphysical concepts. (Schmitt 2008, pp. 45-46)

A clear summary statement of the relevant connections between juridical concepts and encompassing metaphysical-theological concepts is provided in the following:

The presupposition of this kind of sociology of juristic concepts is thus a radical conceptualization, a consistent thinking that is pushed into metaphysics and theology. The metaphysical image that a definite epoch forges of the world has the same structure as what the world immediately understands to be appropriate as a form of its political organization. (Schmitt 2008, p. 46)

Is Schmitt's emphasis on tracking the theological and metaphysical setting of fundamental legal concepts solely a matter of adopting a particular methodology which is useful in clarifying, as a matter of historical scholarship, a link between the conceptual analysis of fundamental legal concepts and a broader 'ideological' context? In this sense, it seems difficult to conclude that Schmitt's work emphasizes the autonomy of the political founding moment in so far as it appears to be determined by influential ideas within its social setting. Arguably, however, Schmitt wants to show that fundamental legal concepts like 'legitimacy', 'sovereignty', 'human rights' and so on cannot be reduced to procedural or technical dimensions through which they serve certain social goals and purposes but they instead have to be rooted in the formation of a broader world-view in a way that has intra-systematic effects on law application. Such a broader world-view can in turn be seen as what is substantially at stake in the political 'moment' that constitutes a set of inter-related juridical concepts and practices. It is then in relation to this underlying political connection between a world-view and the juridical concepts that issue from it that it is possible

\footnotetext{
4 Schmitt (2008, p. 45). An implication of this conception of the sociology of concepts is that it is not a case of referring to historical or sociological context in an explanatory or deterministic sense. Rather, it seems to be a way of expanding an understanding of the broader intellectual context of the concept under examination. As he puts it, '...this sociology of concepts is concerned with establishing proof of two spiritual but at the same time substantial identities.'
} 
to situate some of the contributions Schmitt made to topics of perennial and contemporary controversy such as those of the state of exception and of legal interpretation. For example, in respect of the topic of legal interpretation, Schmitt insists that: 'Every general norm demands a normal, everyday frame of life to which it can be factually applied and which is subjected to its regulations. The norm requires a homogenous medium' (Schmitt 2008, p. 13). Such a 'homogenous medium' or 'normal, everyday frame of life' is arguably invoked by Schmitt with reference to the metaphysical view that subtends the juridical concepts of the system.

Schmitt's reflections on the sociology of juridical concepts indicate an important connection between the moment of the political and the broader metaphysical worldviews characteristic of a certain society. Such considerations already bring theology (in a broad sense) and the political into some kind of relation. The entire picture on Schmitt's concept of political theology needs to be completed by considering the theme of sovereign decision and the theme of political antagonism. In terms of his polemic with liberal constitutionalism, the basic structure of legal concepts and of the way they are interpreted further enables Schmitt to develop an emphasis on the concept of 'sovereignty' and the related concept of the 'state of exception' as the ongoing and omnipresent moments in the legal system that relates the application of law to the underlying metaphysical world-view. Accordingly, Schmitt states,

The sovereign produces and guarantees the situation in its totality. He has the monopoly over this last decision. Therein resides the essence of the state's sovereignty, which must be juristically defined correctly, not as the monopoly to coerce or to rule, but as the monopoly to decide. (Schmitt 2008, p. 19)

The systematic nature of the 'state of exception' as a consequence of the need for judgment in relating the legal order as a whole in its application to the particular case is shown in the following quotation:

Every concrete juristic decision contains a moment of indifference from the perspective of content, because the juristic deduction is not traceable in the last detail to its premises and because the circumstance that requires a decision remains an independently determining moment. (Schmitt 2008, p. 30)

The polemic with liberalism is further sharpened by the discussion in The Concept of the Political which seeks to highlight a connection between the sovereign decision governing the continuity of the 'normal situation' and the existential stakes of the distinction between the 'political friendship' possible within the 'normal situation' and enmity with the actual and potential human existential possibilities that challenge this situation (Schmitt 1996). This intuition concerning the basic linkage between political theology and the so-called friend-enemy distinction provides the basis for Schmitt's distinctively 'antagonistic' reading of the political. Overall, Schmitt's polemic with liberalism consists of two stages: most fundamentally, a critique of an overly abstract idea of the rule of law that reduces law to a mere instrument of social co-ordination and second, a critique of its emphasis on a deceptively dialogic mode of politics as an evasion of the moment of sovereign decision 
in antagonism, a decision which, for Schmitt, is the only way law will recover its existential dignity.

In summary, what emerges from Schmitt's sociology of juridical concepts, the idea of sovereignty and the notion of political antagonism is the notion of sovereignty as a form of radical decisional capacity related to its grasp of the overall structure of social and political order in terms of underlying world-view and in terms of its capacity to shape relations of friendship and enmity. In this way, the political/politics distinction is mapped onto a distinctive form of fundamental political theology. Schmitt's particular arrangement of these ideas has been re-appropriated within modern constitutional theories seeking to draw on the distinction between 'politics' and 'the political'. Schmitt's intention, with his emphasis on the concept of the political, seems to be to reinforce a conservative or authoritarian politics, where the function of the sovereign grasp of the moment of the 'political' is intended to ensure the continuity of a given social and political order-shaped by a particular world-view-within the contingent realm of political action. However, it is easy to see how the idea of an antagonistic sovereign decision could also invigorate a politics seeking to inaugurate more radical forms of social transformation.

Accordingly, Carl Schmitt's work helps to discover a broader context and agenda for reflection regarding the problems of contemporary constitutionalism and this is connected with a wider turn to consider the significance of the distinction between 'politics' and the 'political', the role of political theology and the notion of antagonism in relation to fundamental problems of political legitimacy.

\section{Section 2: The Secularization Thesis}

In the following sections, I would like to situate this reflection on the fundamental character of modern constitutionalism and in particular the concepts of the political and of political theology within a more historical setting. This setting can then be used to explore, in the concrete setting of modernity, the foundational problematic of Schmitt's work in general; namely, his interest in basic metaphysical world-views and their relationship to fundamental juridical concepts of sovereignty and legitimacy. In brief, this involves a direct engagement with the topic of political theology, and its relation to the systematic problem of legitimacy in modernity. In order to delimit the discussion of Schmitt's work in the following sections, I will accordingly seek to focus the treatment of his work through a distinctive foundational problem; namely, that of the problem of legitimacy in modernity or, as Blumenberg has formulated it, the problem of the legitimacy of the modern age. Blumenberg's work is particularly useful in focusing this problem because he establishes a theoretical framework that allows systematic rather than partial and discrete problems of social and political order to be investigated by means of an historical narrative that unlocks the fundamental questions of legitimacy to which precisely these systematic forms of social and political life are the response. Blumenberg's work engaged directly with the underlying problematic of Schmitt's earlier work; namely, the role of political theology in the context of the modern epoch and Schmitt's return to examine this 
theme in critical dialogue with Blumenberg in Political Theology II indicates the acuity of the challenge from Schmitt's standpoint.

Blumenberg's work in this regard is framed by a critical reaction to a broader thesis in the field of the history of ideas relating to the concept of legitimacy in the modern era; namely, the secularization thesis developed by Karl Löwith in his book Meaning in History (1949). This thesis is taken up in his own way by Schmitt in arguing for the perennial function of political theology even in the context of modern constitutionalism. Löwith, in contrast to Schmitt, offers a fairly specific account of the form of political theology associated with modernity; namely, one connected to historical development and its overarching meaning and direction. The subject of Meaning in History is the 'philosophy of history' which Löwith defines as 'a systematic interpretation of universal history in accordance with a principle by which historical events and successions are unified and directed toward an ultimate meaning' (Löwith 1949, p. 1). From the outset, then, we can see the potential relationship that exists between the idea of the philosophy of history, and the sort of political formation of a world-view that fits the Schmittian concept of political theology. In this section, Löwith's basic position will be set out and discussed.

The point that Löwith ultimately wants to make in his discussion of this subject, which is traced back through a number of authors such as, at one end of the historical spectrum, the nineteenth-century historian Burckhardt and, at the other, the fifthcentury Christian writer, Orosius, is that philosophy of history draws its basic conceptual strategies from the theology of history. As Löwith puts it, '...philosophy of history is...entirely dependent on theology of history, in particular on the theological concept of history as a history of fulfilment and salvation' (Löwith 1949, p. 1) Summing up his thesis he states, 'philosophy of history originates with the Hebrew and Christian faith in a fulfilment and it ends with the secularization of its eschatological pattern' (Löwith 1949, p. 2) In this way, Löwith develops the idea that the fundamental world-view of modernity is based on a 'secularization' of categories of understanding drawn from a theology of history grounded in the biblical heritage of Judaism and Christianity.

This theme of 'secularization' is, of course, also invoked by Schmitt in his discussion of the concept of sovereignty in Political Theology. To quote the entire sentence in which he makes perhaps his most well known claim:

All significant concepts of the modern theory of the state are secularized theological concepts not only because of their historical development - in which they were transferred from theology to the theory of the state, whereby, for example, the omnipotent God became the omnipotent lawgiver - but also because of their systematic structure, the recognition of which is necessary for a sociological consideration of these concepts. (Schmitt 2008, p. 36)

Recalling the parallel with Schmitt's idea of secularization is useful in connection with this discussion because it emphasizes the role played by concepts in contemporary politics that perform the same function as theological concepts in articulating an overarching comprehensive world-view which in turn provides the basis for the operation of an interlinked set of social and political practices. In other words, such concepts are used to articulate the basis for the 'systematic structures' invoked 
by Carl Schmitt in this quotation from Political Theology. Beyond Löwith and Schmitt's initial work on this theme of secularization, it is also worth noting the way in which it has been taken up by writers like John Milbank. Writing in a more postmodern context, Milbank makes the important point that the 'secularization' thesis helps to develop a genealogy of the contingent and debatable theological origins of certain forms of modern sociological and constitutional thinking that understand modern principles of social understanding, such as those of secularism, liberalism and progress, in an axiomatic or 'essentialist' manner (Milbank 2006).

\section{Section 3: Blumenberg's Challenge to the Secularization Thesis}

In this section, we will set out how Blumenberg challenges Löwith's secularization thesis (and by extension Schmitt's) with regard to the legitimacy and applicability of, what we can term, the concept of political theology of the modern epoch. At its core, Blumenberg's response to Löwith can be construed as involving a fundamental re-interpretation of the idea of philosophy of history and a reassessment of what is in fact at stake in it. For Löwith, the modern idea of a philosophy of history is necessarily set up as an (illegitimate) transposition of the Christian theological concept of the history of salvation (which can admittedly take forms as different as the historical consciousness of Marx, Comte or Burckhardt). This transposition necessarily has political implications in that it involves immanent eschatological ideas and frameworks that establish patterns for social transformation. The alternative to the transposition of a theological concept of history is, for Löwith, another sort of theology or cosmology that situates historical events within a different form of understanding of humanity and its relation to an ultimate ontology of being and destiny: in his case, the Greco-Roman concept of the cyclical nature of fortuna. For Blumenberg, the basic setting within which the philosophy of history operates is narrower than Löwith's cosmological setting. The proper role of a philosophy of history is to set out the historical context of the problems that define a specifically secular set of questions regarding the 'reliability' of the basic presuppositions underpinning contingent forms of public order. Thus, the problem of regime legitimacy is confronted at the level of effective historicity rather than that of metaphysics. In other words, through a careful analysis of its historical nexus, Blumenberg's ambitious work seeks to prise the problem of legitimacy in modern societies from the grip of an overarching political theology in which the framework of the 'political' is established in and through a sovereign decision and with a definite metaphysical view at stake.

In a sense, Löwith might be said to anticipate the possibility of taking this more modest approach to resolving the legitimacy of modernity's conception of itself through the philosophy of history. After mentioning Burckhardt's more sceptical conception of historical existence, the way he had 'dismissed the theological, philosophical and socialistic interpretations of history' and ultimately his reduction of history to 'mere continuity, without beginning, progress, or end', Löwith however goes on to criticize this as an overemphasis on 'mere continuity' and as a 'poor reminder' of a 'fuller notion of meaning' (Löwith 1949, p. 192). He then goes on to 
diagnose this 'overemphasis' on historical continuity as 'a product of our alienation from the natural theology of antiquity and from the supernatural theology of Christianity' (Löwith 1949, p. 192). However, this type of reply appears to underestimate the key challenge of Blumenberg's work which is precisely to propose a way of distancing the historical understanding of the legitimacy of particular forms of social order from the cosmological, eschatological or quasi-eschatological presuppositions that, in Löwith's mind, necessarily accompany it.

If this attempt at re-assessing the type of historical self-understanding of modernity is at the methodological core of Blumenberg's approach, what consequences does he draw from it and how does it relate to our central theme here, the nature of constitutional legitimacy in modernity? Blumenberg's primary concern in The Legitimacy of the Modern Age is to defend a renewed understanding of the progressive character of history in modernity and crucially of a relatively tentative form of legitimacy that can distance itself from the legacy of political theology. To provide a brief summary of these points, it is worth beginning with the problem of legitimacy which is the more complex of these two points. For Blumenberg, the problem of legitimacy posed in the modern age emerged out of a specific tension in the world-view of medieval Christendom that had prevailed following the collapse of pagan Rome and survived even the collapse of Roman secular power. In line with other historians of ideas, like Erik Voegelin (see Voegelin 2000), he highlighted the importance of a theological controversy between orthodox Christianity (whose principal advocate and representative figure was St. Augustine) and Gnosticism. For now, the key point that was at stake in this debate, which took place in different forms, might be described, to use a slightly different term than Blumenberg here, as the problem of ontological security. How can trust and confidence be sustained in a common world despite manifest flaws: wars, dissensions and so forth? The debate concluded, in Blumenberg's view, with an affirmation of an orthodox doctrine of divine omnipotence and providence which did not fully resolve all the questions posed by the Gnostic challenge. This resulted in a crisis of confidence in the role played by Christianity in sustaining public culture and the search for alternatives, a crisis of confidence and an ensuing search which, for Blumenberg legitimated, in historical terms, the 'modern' option eventually settled on.

The modern alternative to the world-view of medieval Christendom was a vision of a comprehensive view of historical progress which Blumenberg terms the ideal of self-assertion'. One of the key points about 'self-assertion' is not only that it responds to the specific historical challenges of legitimacy but also that, according to Blumenberg, it was not a 'secularization' of a previous theological concept. For Blumenberg, progress as an ideal of self-assertion was a generalization of a notion of progress which was generated by specific sorts of procedures and advances made initially in limited technical and scientific fields. At the same time, the generalization of this idea enabled a wider culture to articulate an historical self-understanding which allowed it to recover a sense of reliability and trust in its world and environment based on a more modest sense of progress and self-assertion.

In addition to setting out the ideal of self-assertion, a significant part of Blumenberg's work is also devoted to diagnosing and explaining the important sociological and ideological idea of 're-occupation'. This idea is used to account in part for 
the fact that the notion of legitimacy in modernity is a contested terrain. According to him, certain ideas that belong to traditional world-views (like for example that of the significance of history as a whole) do not entirely disappear. Rather, certain of their 'functions' are transposed into symbolic forms consistent with a modern world-view such as, for example, the ideology of secular progress. Generally, it is important to note that, whilst Blumenberg uses the idea of re-occupation to account for these symbolic transpositions, he is generally critical of the procedure itself. It is this idea of 're-occupied' functions that is used to develop a focused critique of Carl Schmitt's work and, in particular, his insistence on the perennial nature of political theology.

The debate between Schmitt and Blumenberg is complex and resulted in a number of important revisions to The Legitimacy of the Modern Age and in particular to Part I, chapter 8. We will examine certain strands of this debate at a later stage in the article however the key point of Blumenberg's critique of Schmitt might be said to be that he disputes the connection Schmitt seeks to forge between legitimacy and the sovereign decision to maintain a comprehensive 'normal situation' in the face of possible enmity. Blumenberg insists that such a notion of legitimacy is inappropriate in the context of the modern principle of self-assertion which demands a more pragmatic approach to the development of collective institutions rather than one that appeals to their capacity to enact and sustain an absolute form of commitment to an overarching world-view:

When it is no longer possible to believe that the decision between good and evil is going to occur in history and is immediately impending, and that every political act participates in this crisis, the suggestiveness of the 'state of emergency' as the normal political state disappears. (Blumenberg 1983, p. 91)

At the same time, he recognizes that Schmitt's notion of legitimacy does draw on a certain sort of social phenomenon; namely, the residual and widespread need for a collective vehicle of existential commitment. The ongoing appeal to an absolute existential political commitment as it exists in modernity, according to Blumenberg, is not tied to an 'external' theological or metaphysical point of reference but is more flexible in identifying symbols of identity, friendship and enmity. ${ }^{5}$ That this type of phenomenon cannot be described as a 'secular' form of 'political theology' seems to follow precisely from the relative flexibility of the object of this sort of commitment. It both belongs to modern politics but in Blumenberg's view sits awkwardly with its central principle of legitimacy, the largely pragmatic ideal of self-assertion.

In sum, we can say that Blumenberg takes the view that the Schmittian concept of legitimacy captures a genuine sociological reality: an anachronistic need for commitments to social and political forms to be understood in terms that are absolute

\footnotetext{
5 He gives as an example of shifting 'absolute' forms of identification, the move from politicized confessional identities to national identities: '... what happened was that the intolerability of the factionalization of absolute positions within the state was counteracted by the transfer of the category of the unconditional friend/enemy relation to the conflicts between the national states that were in the process of integrating themselves' (Blumenberg 1983. p. 90).
} 
in an existential sense. This need, however, has to be understood as a problematic and distorted 're-occupation' of a requirement of absolute commitment to symbols of legitimacy which is no longer appropriate. If Blumenberg is right, we can say that the underlying problematic of Schmitt's work, the problem of political theology, can be seen as of relative importance and as ultimately unnecessary in understanding the sources of legitimacy in modern legal systems. Although we might say that the danger of 're-occupations' are always present and that careful consideration of Schmitt's work helps to clarify this point, Blumenberg's work ultimately supports a radical scepticism towards the systematic introduction of Schmittian themes into the understanding of contemporary constitutionalism. A key Schmittian theme that Blumenberg's work does not necessarily unpick is the political/politics distinction. Although the idea does not appear to be particularly important to him, it might still retain a methodological utility where the 'moment' of the political is understood as referring to a broader process of historical development. At the end of this examination, however, a difficult question remains for Blumenberg: does the ideal of selfaffirmation present an adequate understanding of the problem of legitimacy in modern constitutionalism?

\section{Section 4: Blumenberg and Ideal of Self-Assertion: Stat pro Ratione Libertas, et Novitas per Libertate}

As we have seen, Blumenberg's work on the historical setting of the development of the 'self-assertive' ethos of modernity arguably helps to clarify how a strong concept of sovereign decision performs certain sorts of functions that are determined by a symbolic process of legitimation that in other, more critical, respects has been set aside. Accordingly, Blumenberg's work might most straightforwardly be interpreted as preparing the way for a more modest understanding of constitutionalism in terms that would owe more to a classical liberal form of pre-political right like that of John Locke or, perhaps, the more social liberal contractualism of John Rawls. In place of ideas like that of collective self-determination and forms of secularized political theology, it would be possible to conceptualize something like a 'global' setting for what Schmitt characterizes in his critical discussion of Blumenberg in Political Theology II as a more technical and neutral mode of constitutionalism, which would be aimed at securing scientific neutrality, technical and industrial freedom of production and guaranteed conditions for 'free human utilization' on the basis of widely agreed universal parameters. At the same time, Schmitt's pointed rejoinder to the self-assertive ethos put forward by Blumenberg must be weighed carefully. Schmitt poses the following question to Blumenberg: 'Which of these three freedoms is intrinsically the most intense and aggressive: scientific neutrality, the technical and industrial freedom of production or the arbitrary nature of free human utilization?' (Schmitt 2008, p. 130).

In framing the question, Schmitt anticipates the probable reply that a negative evaluation of the 'aggressive' potential implied in the ideal of free human realization would in turn imply that only an objective scheme of values inconsistent with the ideal of self-assertion can offer any reassurance. As he puts it, 'Should this 
question be ruled out of court on academic grounds, because the word "aggressive" has become value-free, then the situation would be clear: stat pro ratione Libertas, et Novitas per Libertate [Freedom replaces Reason, and Novelty replaces Freedom]' (Schmitt 2008, p. 130). The very idea of a scheme of values, acting as a secure ontological and evaluative precondition of agency has apparently been set aside at the outset in the diagnosis of an historical shift underpinning the birth of the idea of 'self-assertion' and its accompanying reconfiguration of standards of political legitimacy. Schmitt's somewhat enigmatic answer to this might be interpreted as follows: that there is nothing in the idea of self-assertion that can ground any sort of settled ethic of mutual respect capable of moderating the sort of practical efforts that might be made to reconfigure each possible social and political form of self-assertion. In other words, modern human agency is paradoxically constrained to comply with an overriding commitment to applying novel possibilities and social forms, combined with the 'creative destruction' that this implies, with no particular ground for an ethical warranty for the concrete actions taken.

How is it possible for Blumenberg to answer this problem? In one sense, a straightforward response might simply be to insist on a necessary sort of mutuality and reciprocity inherent in the general affirmation and guarantee of a right to 'free human utilization' of scientific advances and the potentialities of technology and production processes. However, this solution is not as straightforward as it might first appear. At a deeper level, we arguably need to return to the terms in which Blumenberg framed the leading metaphysical-political problem of modernity in order to clarify this idea and to explore the tensions that might exist here with the overarching concept of self-assertion.

For Blumenberg, the roots and motives for the modern ideal of self-assertion emerge from a particular constellation of ideas characteristic of medieval Christendom. The debate between Gnosticism and orthodox Christianity which he sees as framing medieval Christendom was, in a prima facie sense, a problem concerning 'trust' in the created world which largely posed problems concerning the relationship between creation and questions of personal salvation. Blumenberg sees this debate as one concerning personally indexed soteriology and this is probably a relatively accurate way of understanding this controversy. At another level however, and in terms of the connection between metaphysics and politics, it might be said that another question which was at stake in this debate, or at least an important aspect of its overall dynamic and importance, was the reliability of the 'world' understood in a more social and political sense.

As Blumenberg makes clear, the soteriological problem, posed by Gnosticism, of the relationship between creation, providence and salvation was ultimately supplied with a systematic doctrinal resolution through the Augustinian hermeneutic of free will, original sin, grace, predestination and election. For Blumenberg, however, this 'first overcoming' of Gnosticism was unsuccessful and it required a 'second overcoming' in the modern ideal of self-assertion. Accordingly, Blumenberg sets out the following rather stark verdict on Augustinianism:

The Gnostic dualism had been eliminated as far as the metaphysical world principle was concerned, but it lived on in the bosom of mankind and its history as the absolute separation of the elect from the rejected. This crudity, 
devised for the justification of God, had its unspoken irony in the fact that the absolute principle's responsibility for cosmic corruption - the elimination of which had been the point of the whole exercise - was after all reintroduced indirectly through the idea of predestination. (Blumenberg 1983, p. 155)

Arguably, however, part of what took place in the development of the post-medieval engagement in this problem was a differentiation of the soteriological dimension of the 'Gnostic' problematic from the ethical-political dimension of trust and confidence in social and political institutions. This was eventually expressed in a distinction between the interrelated spheres of 'grace' (soteriology) and 'nature' (temporal order) developed in medieval scholasticism. ${ }^{6}$ Leaving aside his rather one-sided interpretation of the doctrine of predestination, Blumenberg's sense that a 'second-overcoming' of Gnosticism was indeed required is arguably based on the premise that Augustianism failed to offer a coherent basis for a 'public metaphysics' capable not only of resolving problems internal to Christian theology and proclamation, but simultaneously providing a wider basis for civic co-operation in quotidian and secular affairs. It is Blumenberg's expectation that Augustinianism was bound to supply a direct answer to this second type of issue grounded in its soteriology that leads him to diagnose an insufficiency and to search for a 'second-overcoming' of Gnosticism in the ideal of selfassertion. As such, there seems to be an arbitrary basis for Blumenberg's insistence on the necessity for the ideal of self-assertion as a 'second-overcoming' of Gnosticism, something which supports Schmitt's critique as to its essentially 'aggressive' stance.

A last step would be to question the appropriateness of the ideal of self-assertion for modern constitutionalism as Blumenberg interprets it. Whilst, as we have seen, Blumenberg goes some way to detaching social and political legitimacy from a secularized eschatology, the ideal of self-assertion arguably still attempts, to use his own terminology, to 're-occupy' a position or function served by the idea of trust or confidence in a cosmic order or mythical framework, an order connected with a particular social and political regime. It arguably does this through setting out the question of 'trust' in ontological or mythical terms; that is, as a prior 'setting' for politics requiring ultimate allegiance. For Blumenberg, political theologies secured stability through a mutual confidence in the ontological continuity of society's 'basic structure' with a certain order of being or with a mythical past. Whilst, for Blumenberg, modernity sets such an order of being or mythical past aside in order to engage in a project of self-assertion, it is arguable that this ideal of self-assertion is still determined by what might be described as an ultimate ontological setting. In that sense, self-assertion might also be seen as performing a 're-occupied' function. One way of putting this is that the 'teleological' framework once supplied by the order of the cosmos or of a primordial myth is transcribed to the plastic sensibility of selfassertion: an unqualified aesthetic confidence in the variety of future possibilities it may engender. ${ }^{7}$ Trust, therefore is still implicitly understood in mythical or, in

\footnotetext{
${ }^{6}$ For a useful introductory discussion of this complex distinction see Swafford (2014).

7 Blumenberg describes the ethic of self-assertion as 'an existential program, according to which man posits his existence in a historical situation and indicates to himself how he is going to deal with the reality surrounding him and what use he will make of the possibilities that are open to him' (Blumenberg 1983, p. 133).
} 
a modern sense, aesthetic terms as an ultimate object of affective allegiance, even where Blumenberg, as against Nietzsche, draws attention to its unmasterable historical constraints. An alternative would be to think about the proper characteristics of a secular civil order in terms of the dynamics of an inter-personal sensibility of trust that does not require a necessary reference to a broader legitimating myth: a quasiontological setting of ultimate political allegiance. In this sense, the ideal of selfassertion and its 'aesthetization' of the principle of ontological trust would no longer form an appropriate basis for the legitimacy of a secular political regime that can set aside legitimation on the basis of a political theology.

\section{Section 5: The Problem of Political Theology: From Antagonism to Association}

In this section, I would like to defend an idea of contemporary constitutionalism that is grounded in civic association rather than forms of contestation connected to existential identification with a polemically staked out world-view (a political theology). This is done by focusing on a problem left over from the critique of Blumenberg's thesis concerning the centrality of the ideal of self-assertion to the legitimacy of the central institutions of modern societies. This problem concerns the nature of the mutually sustained interpersonal forms of reliability or trust that underpin the stability of social and political institutions. Such an interpersonal sense of trust can then form the founding basis of quotidian politics, challenging Carl Schmitt's alignment of the founding moment of the political and political trust with the antagonistic distinction between friend and enemy, a distinction which has as its object a politically secured worldview. As we have seen, Carl Schmitt in Political Theology II presents an incisive critique of Blumenberg's ideal of self-assertion for its unqualified aesthetic adherence to modern processes of social transformation and the associated forms of social and political antagonism this implies. The reservations expressed by Schmitt are, as have been discussed, not adequately addressed due to the implicitly mythical dimension to the ideal of self-assertion itself. As we have suggested, the mythical frame associated with the value of self-assertion is perhaps an attempt to 're-occupy' some of the functions performed by the 'political theologies' of pre-modernity (as well as the modern ideal of secular progress) in legitimating social institutions.

In the light of this, the key question is: what conclusions should we draw from Schmitt's critique of Blumenberg in Political Theology II? If we accept the critique, arguably two sorts of strategies present themselves. On the one hand, we might choose to affirm Schmitt's exposure of the antagonistic underpinnings of the modern ideal of self-assertion in an effort to moderate any of their unmediated implications. This is one way of looking at the Schmittian-influenced idea of agonic constitutionalism. On the other, we might look for ways in which 'reliability' and 'trust' in civic institutions might be sustained without reference to the antagonistic processes associated with the Schmittian concept of the political. This second strategy is the one that will be explored in this section.

Defending this second understanding of contemporary constitutionalism entails an engagement with the first 'agonic' strategy of interpreting the outcome of the 
Schmitt-Blumenberg debate. According to this view, both Schmitt and Blumenberg's work attest to the on-going significance of an essential antagonistic dimension in politics. In addition, Blumenberg's work, in the light of Schmitt's critique, suggests that the antagonistic dimension of politics is essential even for a self-designated democratic and progressive politics based on the modern idea of self-assertion. On the agonistic view of liberal-democracy, the self-assertive ethos of modernity does indeed generate specific social practices and political institutions which necessarily involve the unilateral imposition of specific forms of social organization in ways that are problematically arbitrary in terms of prior normative principle. However, it would see in the very continuity of the 'novelty' and drive to social transformation implicit in the overarching precedence of the ethic of self-assertion, a jurisprudential source of the various forms of rights, institutions, procedures and so forth that can be associated with liberal principles. This allows what would otherwise amount to a predictable exercise in social coercion to be contested and enlivened by the disruption of bureaucratic routine and the multiple shifts in demand characteristic of market societies. The ideal associated with this particular approach to re-thinking liberal constitutionalism through the work of Carl Schmitt is termed 'agonic democracy' and is associated in particular with the work of Chantal Mouffe.

For Mouffe, liberal-democracy involves a form of political self-understanding that holds two distinct moments in tension. These two moments are: first, 'democracy' as the point where civic engagement generates, through the exclusion of alternatives, particular sorts of borders and internal boundaries marking a 'shared' form of social and political life between equal citizens; and second, 'liberalism' as the rights and procedures that permit the problematization of what has thus been put in common. A useful summary of all this is contained in the following statement which characterizes the twofold 'logic' sustaining the specificity of liberal democracy:

The democratic logic of constituting the people, and inscribing rights and equality into practices, is necessary to subvert the tendency towards abstract universalism inherent in liberal discourse. But the articulation with the liberal logic allows us constantly to challenge - through reference to 'humanity' and the polemical use of 'human rights' - the forms of exclusion that are necessarily inscribed in the political practice of installing those rights and defining which is going to rule. (Mouffe 1999, pp. 43-44)

It is useful to see agonic democracy as an attempt to bring together, in a more productive sense, the ideal of self-affirmation stemming from Blumenberg's work and Schmitt's emphasis on the necessarily antagonistic dimension of identity formation in politics. However, the synthesis it can be interpreted as effecting is at the cost of excluding important dimensions of the work of these thinkers. In Blumenberg's case it fails to do justice to the inherited historical problematic of how trust in common political and social institutions is sustained. In addition, Schmitt's work clearly does not straightforwardly affirm the priority of a general form of 'antagonism' in social and political relations. The political in the strict sense only refers to enmity in view of a specific object of metaphysical or theological political allegiance. Antagonism is always related to the theme of political theology. As an object of allegiance, an ethic of the political, in Schmitt's sense, would see antagonism as the route to a 
precarious social stability centred on a shared, or at least an existentially and collectively compelling world-view, rather than further contestation.

A liberal form of agonistic democracy can perhaps feel comfortable with leaving this difference in spirit and intent stand. However, one of the central concerns of agonistic democrats was to offer an antidote to what they see as excessively depoliticized forms of global governance: 'Only by coming to terms with the double movement of inclusion and exclusion that democratic politics entails can we deal with the challenge with which the process of globalization confronts us today' (Blumenberg 1983, p. 52). It seems that Schmitt's most convincing challenge to global governance relates to the danger of the predominance of technical and systematic forms of co-ordination operating, due to precisely their instrumental character, within a 'global' epistemic sphere. At the core of this challenge is a stress on the importance of interpersonal trust in the form of political friendship as one of the key dimensions of the lifeworld sustained by political action. ${ }^{8}$ Over and above its ultimate 'antagonistic' stakes, Schmitt's work challenges the view that a substantial ethic of political friendship can be sustained given predominant forms of instrumental rationality. Schmitt's own critique of technocratic and de-politicized forms of governance implies that their deficits lie not only in removing issues of political contestation from the agenda but also in setting aside issues of solidarity and the common good. This leaves bureaucracy and market rationality as the only practical means of social co-ordination.

A further question now arises: whether the political solidarity, required to move beyond antagonism and market co-ordination, is to be understood in contingent terms as a relatively stable and coherent order in the context of the continuity of secular history or whether it should be seen as directly connected to a deeper overarching world-view or underlying quasi-ontological setting? Another way of posing this question is: can political allegiances claim to be binding existentially in a strong ultimate or in a weaker more relative sense? It is here that the work of Erik Peterson and his critique of Carl Schmitt is important in challenging the appropriateness of the category of political theology for secular forms of political authority (Peterson 2011).

The central text in which Peterson challenges the work of Carl Schmitt in developing the idea of political theology in connection with political legitimacy and political friendship is entitled 'Monotheism as a Political Problem'. Its direct import for these questions, certainly in so far as they carry a contemporary resonance, is not immediately apparent. However, in the same way as Blumenberg, the sorts of questions raised by Schmitt regarding the conceptual relationship between juridical concepts and metaphysical-theological concepts are approached, by Peterson, not in polemic-existential terms but in terms of effective history. As with Blumenberg, the attempt to frame these issues in terms of effective history involves a form of historical understanding connected to evaluating substantive questions regarding legitimacy. As discussed in section one, the problems of legitimacy and existential

\footnotetext{
${ }^{8}$ Colliot-Thélène (1999) usefully explores Carl Schmitt's work as an attempt to challenge Max Weber's reduction of law (and constitutionalism) to a matter of instrumental technique.
} 
trust, the problems concerning the founding moment of the political, are seen by Schmitt as resolved within the crucible of a polemical sovereign decision in the present 'moment', through which friend and enemy are seen and distinguished. Blumenberg and Peterson see the 'moment' of the political less as coming to resolution at an instant of political decision than as worked out through a compelling long-term narrative understanding of a larger historical situation. Hence the sense in which Schmitt saw the need to return to a dialogic confrontation with these two thinkers in Political Theology II in order to vindicate the fundamental necessity of political theology and to defend it against these attempts to relativize its historical importance.

Like Blumenberg, Peterson sees the critical questions surrounding the relationship between political theology and legitimacy as being shaped, in an historically decisive manner, in the period of the early church and in the context of the polemic between the early church fathers and pagan writers. To summarize a more detailed argument, Peterson notes how the problematization of political theology arose out of polemical issues regarding the (negative) effect of Christianity on the stability of the Roman Empire. The Christian defence to this was to argue that the de-legitimation of various national forms of civic religion or political theology, which Christianity set in motion, strengthened the more universal form of the Roman Empire. At the same time, the more universal political form could be supported by certain sorts of arguments from providence or by a broader consideration of the historical situation. However, Peterson suggests that the Christian arguments that supported the claims of the Roman Empire were, crucially, only advanced in a historically relative rather than in an absolute sense so that they did not amount to a replacement political theology. In addition and in summary of his detailed argument on the point, Peterson claims that further examination of the question by Christian theologians revealed that there were structural obstacles within Christianity itself to developing a political theology capable of commanding ultimate allegiance to the imperial polity. The first of these was drawn from the topic of salvation history and is relatively well known as the classic Augustinian argument concerning the relative and non-ultimate authority of secular institutions in the light of the coming Parousia: the so-called Two Kingdoms Theology. ${ }^{9}$ The second point is less well known but draws on arguments surrounding the difficulties of drawing theological-political analogies from the nature of the Trinity, when the drawing of such metaphysical analogies had been a strategy of previous 'monotheistic' political theologians writing from the perspective of pagan forms of natural theology. He concludes his analysis with the following summary, a summary which appears in addition to have Schmitt in its sights:

not only was monotheism as a political problem resolved and the Christian faith liberated from bondage to the Roman Empire, but a fundamental break was made with every 'political theology' that misuses the Christian proclamation for the justification of the political situation. (Peterson 2011, p. 104)

\footnotetext{
${ }^{9}$ Löwith (1949, p. 189) also testifies to these points: 'As an eschatological message of the Kingdom of God the theology of the New Testament is essentially unconcerned with the political history of the world' and 'Such a theological understanding of the history of mankind cannot be translated into worldhistorical terms and worked out into a philosophical system.'
} 
Of course, Peterson advances an assessment by a Christian theologian and historian of the validity of the idea of a political theology as a source of legitimacy and of ultimate existential allegiance. As Carl Schmitt's reply to him in Political Theology II indicates, he is prepared to rule Peterson's intervention as beside the point in so far as the problem of political theology is essentially juridical in nature. Ultimately this reply relies on an essentially circular basic position in which the very notion of the political is posited as an autonomous field due to the fact that it is identified entirely with the sovereign decision positing a distinction between friend and enemy. At the same time, Schmitt seeks to support this position on the autonomy and priority of the moment of the political by linking this moment of sovereign decision with the theme of political theology. In this way, the sovereign decision can be presented as an autonomous type of decision and act, but one with society-wide implications. As Blumenberg's work plausibly indicates, however, questions of legitimacy are determined by an effective historical context which involves the sorts of metaphysical and theological questions and claims that Schmitt implausibly claims can only be resolved in the 'moment' of sovereign decision. In that case, in what ways does Peterson's work shed light on these historically conditioned questions concerning legitimacy?

Peterson's critique of Carl Schmitt suggests that the idea that the 'truth' of a political theology is necessarily a decisive object of ultimate political allegiance and sovereign decision is, at the very least, not required by the broader cultural and historical context determined by the reception of a Christian theology and metaphysics. ${ }^{10}$ In itself, this argument undermines the necessary connection that Schmitt seeks to forge between the very notion of the political and political theology. Does this negative judgment on political theology place a contemporary hermeneutic of Peterson alongside Blumenberg in identifying political legitimacy with a straightforwardly pragmatic ideal of self-assertion mediated by a weak procedural liberal democratic frame? If so, we evidently return to the Schmittian rejoinder and, from there, to agonic democracy as the logical outcome of the discussion.

Further consideration of the possibilities opened up by the historical context discussed by Peterson suggests instead that theological and metaphysical questions regarding the ultimate, ontological reliability of a self-asserted world-view of the sort that preoccupied Schmitt and even (implicitly) Blumenberg, as final terms of political debate, can in fact be supplanted by a more quotidian and crucially interpersonal sphere in which such issues of reliability and trust specific to civic society, with its tragic admixture of imperfect organization, past injustice and coercion, are addressed. Trustworthiness in civic society, on this view, is not the product of an existential commitment to a type of political friendship sealed by adherence to a common world-view forged in relation to a polemical 'state of emergency'. Rather, trustworthiness is worked out as an essentially interpersonal achievement through

\footnotetext{
10 In contemporary political theory Radical Orthodoxy also highlights that the historical narrative of Christianity opens up a new ontology, politics and social formation founded on the priority of peace as a unique alternative to the essentially antagonistic politics of pagan antiquity, liberalism and nihilistic postmodernism. See Milbank (2006).
} 
civic association and dialogue. However such an interpersonal achievement-political solidarity-must be seen as logically prior to any institutionalized private or public right in mediating this distinctive form of civic association.

A 'normal situation' in Schmitt's sense can only be settled and stabilized through a personal solidarity that sustains mutuality of trust in the concrete orders that develop in relation to specific historical challenges and the perennial imperatives and requirements of human nature. In so far as the element of trust, constitutive of the normative character of a certain way of arranging social and political institutions, depends on the formation of an ethic of mutuality in passing through the tragedy of polemic, this implies a role for dialogue in the construction of such institutions. In brief, Peterson's work helps to locate an historical moment at which, in an especially clear sense, the conditions became available for uncovering, under the layers of a complex heritage of political theology, the essential interpersonal and dialogic dynamic of political community. Only this form of solidarity now provides the means for resolving the 'states of emergency' engendered by the tragic antagonisms of political life without default recourse to impersonal bureaucratic and market-based sublimations of these conflicts. In this sense, Peterson was able to state that this historical moment disclosed the end of political theology as an ineluctable horizon of political activity.

Of course, the overall thrust of Schmitt's interwar work was to challenge precisely this type of 'associationalism', which, in his view, risked compromising the stability of any given constitutional regime. After quoting Gierke's characterization of such an 'associationalist' understanding of the normative basis for political regimes, to the effect that, 'The will of the state or the sovereign is not the final source of law but is the organ of the people convoked to express legal consciousness as it emerges from the life of the people' (Schmitt 2008, p. 24, quoting from Von Gierke 1974, p. 31), Schmitt develops his critique of the 'associationalist' perspective in the following terms. According to him, 'The problem that arises is to what extent, with legallogical necessity, every ascertainment and decision contains a constitutive element, an intrinsic value of form' (Schmitt 2008, p. 26). Although Schmitt's sense, set out in this statement, that a personal grasp of the meaning of the 'normal situation' was essential to the operation of a legal order by its officials was sound, the further implication that this was ultimately always dependent on a 'decision' characterized in abstract terms and developed in and through a fundamental polemical stance was arguably insufficient in rooting the problem in a careful analysis of the historical context, revealed by Peterson, that had disclosed new, more authentic ways, in which the personal dynamics of political community could be developed and sustained. Indeed, the emphasis on the importance of personal understanding in the operation of the legal order is more plausibly supported by a dependence on a broader historically evolved social order than through a reliance on the decisionist and polemical energies of the Schmittian sovereign.

A final point to insist on is the need to avoid thinking of the notion of an 'associationalist' constitutionalism as yet another secularized political theology. The idea of dialogue and mutuality can only provide a schematic idea of the solidarity required to sustain a 'normal situation' in which social and political institutions are delineated in ways that command trust and confidence and that can be extended and applied in 
ways that consolidate the coherence of the forms of self-understanding and intelligibility embodied in them. Crucially, the intelligibility of this normal situation depends on the mutuality and dialogue that is sustained in a particular historical context which requires a careful cultural analysis of the type developed by Blumenberg and Peterson. A mechanical application of some kind of social contract theory has the potential to seriously distort the concrete existential questions involved.

\section{Conclusion}

Carl Schmitt's work has rightly prompted political theorists to engage in a deeper reflection on the nature of democracy and modern constitutionalism in the circumstances of globalization and in the context of an increasing dependence on transnational forms of what Habermas terms 'systematic rationality', represented by markets and bureaucracies, for social co-ordination. Concerns have arisen in this context regarding the sources of solidarity and regarding the risks of de-politicized models of governance that block contestation and fundamental social transformation. In addition, his work has also given inspired a more careful examination of the relationship between liberal ideals of the rule of law and problems of state security. Schmitt's work certainly provides an indispensable focus for discussion in these areas. However, in reading Schmitt we need to be careful to problematize his basic concepts at a fundamental level in order to appropriate the insights contained in his work in a productive manner. This was done by examining the connections between Schmitt's conception of the political and related concepts like antagonism and political theology. We set the scene for the discussion by describing Hans Blumenberg's challenge to the idea of legitimacy in modernity as a 'secularization' of an anterior political theology. We went on to explore how, although Blumenberg developed a powerful critique of Schmitt, his alternative ideal of self-assertion arguably did not sufficiently explore the inter-personal and ethical dimensions of constitutionalism. The final section set out an attempt at reconstructing a more definite 'secular' conception of contemporary constitutionalism in which, following Peterson's thesis on the closure of political theology, existential ties of political solidarity are understood as relative to circumstances and open to dialogue through a fundamental mutual recognition of human dignity. This enables a reconstruction of the idea of constitutionalism aimed not so much at antagonistic social transformation or at localizing forms of ultimate allegiance but at stabilizing forms of social and political continuity that can be understood as expressive of principles of mutuality and dialogue. Such a notion of constitutionalism first arose in a specific historical constellation but it remains effective and determining in a global or universal constitutional constellation where antagonistic forms of political theology, and bureaucratic and market rationality, can no longer provide a viable basis for stable political forms.

Open Access This article is distributed under the terms of the Creative Commons Attribution 4.0 International License (http://creativecommons.org/licenses/by/4.0/), which permits unrestricted use, distribution, and reproduction in any medium, provided you give appropriate credit to the original author(s) and the source, provide a link to the Creative Commons license, and indicate if changes were made. 


\section{References}

Blumenberg, Hans. 1983. The legitimacy of the modern age (trans: Robert W. Wallace). Cambridge, MA: MIT Press.

Colliot-Thélène, Catherine. 1999. Carl Schmitt versus Max Weber. In The challenge of Carl Schmitt, ed. Chantal Mouffe. London: Verso.

Flynn, Bernard. 2005. The philosophy of Claude Lefort: Interpreting the political. Evanston, IL: Northwestern University Press.

Lefort, Claude. 1988. The permanence of the theologico-political? In Democracy and political theory (trans: David Macey). Cambridge: Polity Press in association with Basil Blackwell, Oxford.

Löwith, Karl. 1949. Meaning in history. Chicago: University of Chicago Press.

Marchart, Oliver. 2007. Post-foundational political thought: Political difference in Nancy, Lefort, Badiou and Laclau. Edinburgh: Edinburgh University Press.

Milbank, John. 2006. Theology and social theory, 2nd ed. Oxford: Blackwell.

Milbank, John, and Adrian Pabst. 2016. The politics of virtue. London: Rowman and Littlefield.

Mouffe, Chantal. 1999. Carl Schmitt and the paradox of liberal democracy. In The challenge of Carl Schmitt, ed. Chantal Mouffe. London: Verso.

Peterson, Erik. 2011. Monotheism as a political problem. In Theological tractates (Ed. and trans: Michael J. Hollerich). Stanford: Stanford University Press.

Scheuerman, William E. 1999. Carl Schmitt: The end of law. Lanham, MD: Rowan and Littlefield.

Schmitt, Carl. 1996. The concept of the political (trans: George Schwab). Chicago: University of Chicago Press.

Schmitt, Carl. 2008. Political theology II: The myth of the closure of any political theology (trans: Michael Hoelzl, and Graham Ward). Cambridge: Polity Press.

Swafford, Andrew Dean. 2014. Nature and grace. Eugene, OR: Pickwick Publications.

Voegelin, Erik. 2000. The new science of politics. In Modernity without restraint: Collected works, vol. 5, ed. Manfred Henningsen. Colombia: University of Missouri Press.

Von Gierke, Otto. 1974. Die Grundbegriffe des Staatsrechts und die neuesten Staatsrechtstheorien (Part I), Zeitschrift für die gesamte Staatswissenschaft 30. 